Müller, E. A. \& Franz, H. (1952). Arbeitsphysiologie, 14, 499.

Newburgh, L. H. (1950). In Clinical Nutrition, p. 689. [N. Jolliffe, B. F. Tisdall and P. R. Cannon, editors.] New York: Paul B. Hoeber Inc.

Odier, J. \& Mach, R. S. (1949). Praxis, 38, 384. Quoted by McCance, R. A. \& Widdowson, E. M. (195I). Proc. roy. Soc. B, 138, 115 .

Passmore, R., Meiklejohn, A. P., Dewar, A. D. \& Thow, R. K. (1955). Brit. F. Nutr. 9, 27.

Passmore, R., Thomson, J. G. \& Warnock, G. M. (1952). Brit. F. Nutr. 6, 253.

Robertson, J. D. \& Reid, D. D. (1952). Lancet, 262, 940.

\title{
An Analysis of the Gain in Weight of Overfed Thin Young Men*
}

\author{
By R. PASSMORE, A. P. MEIKLEJOHN, A. D. DEWAR \\ AND ROSEMARY K. THOW \\ Departments of Physiology and Medicine, University of Edinburgh and the \\ Metabolic Ward, Edinburgh Royal Infirmary
}

(Received 2 I Fune 1954)

The preceding paper(Passmore, Meiklejohn, Dewar \& Thow, 1955) describes an experiment in which three thin but healthy young men were fed on more food than they needed to maintain their weight. Measurements showed that the excess food was effectively absorbed, but no more was oxidized than could be accounted for by the specific dynamic action of the extra protein consumed. In this paper it is shown that, although all three gained weight, the gain was less than expected had all the excess food gone to make 'obese tissue'. Keys \& Brožek (1953) have suggested that changes in weight of healthy people result from gain or loss of 'obese tissue', which is composed of $62 \%$ fat, $24 \%$ cell mass and $14 \%$ extracellular fluid.

It is a common belief that thin people have some mysterious means of disposing of surplus food. Since these thin men failed to gain as much weight as expected, the observations made on them offer a possible clue towards an understanding of the metabolic mechanisms which determine leanness in some people and obesity in others. Whilst a proper understanding of these mechanisms is unlikely until many more metabolic experiments have been made on human subjects, it is felt that the present observations may be found useful in planning future experiments.

A study is presented of the balances of energy, nitrogen, water, sodium and potassium, measured in these three men during overfeeding. Some inductions are made therefrom about the disposal in the body of the surplus food.

\section{METHODS}

The weights of the subjects were recorded on an old beam balance of the type used by Sanctorius (1614); it can weigh a man with an accuracy of $\pm 5 \mathrm{~g}$. The methods employed for the measurement of energy intake and output and of nitrogen balance are described in the preceding paper (Passmore et al. 1955). The methods used for

- The work was done with the assistance of Elizabeth Mutch, Blodwen Jehu and D. Shirling. 
calculating water balance from the data so obtained are described later in this paper. As a check on the accuracy of the caloric intake as measured by the bomb calorimeter, the food consumed by the subjects was analysed chemically; protein was estimated by the determination of total nitrogen using the micro-Kjeldahl method, fat by Soxhlet extraction with ether, and carbohydrate by difference, except in David's diet, the carbohydrate of which was estimated directly by the method described by Trevelyan \& Harrison (1952). Sodium and potassium were estimated in food, faeces and urine using an EEL flame photometer (Evans Electroselenium Ltd, Harlow, Essex). The food and faeces were heated at $100^{\circ}$ to determine their water content and then dryashed in a furnace at $500^{\circ}$. The ash was extracted with $\mathrm{I} \mathrm{ml}$. conc. $\mathrm{HCl}$ and diluted to appropriate volume.

\section{Gain in weight}

RESULTS

The average daily gains in weight of David, Michael and Sam during the period of overfeeding were 150,175 and $187 \mathrm{~g}$ respectively. The daily excesses consumed by them were 1300,1635 and I 560 net Cal. (see Passmore et al. (1955), Table 6). According to Keys \& Brožek (1953) it requires about 6000 Cal. to put on I kg 'obese tissue', so that our subjects should have gained 220,240 and $260 \mathrm{~g} /$ day. In all three subjects, therefore, the gain in weight was only about $70 \%$ of that expected had it been due to the deposition of 'obese tissue' of the composition described by Keys \& Brožek. It is interesting, therefore, to inquire into the composition of the bodily material responsible for the gain in weight in our three subjects.

\section{Nitrogen balance}

A study of the figures for the nitrogen balances, as set out in Table $\mathbf{I}$, indeed indicates that part of the material responsible for the gain in weight was protein, such as would occur with an increase in cell mass. Whereas during the control period each

Table I. Nitrogen balances ( $g / d a y)$ of thin young men on a balanced diet and during overfeeding

\begin{tabular}{clccccc} 
Subject & Diet & Days & Food & Urine & Faeces & Balance \\
David & Balanced & $1-5$ & $12 \cdot 8$ & $12 \cdot 4$ & $1 \cdot 5$ & $-1 \cdot 1$ \\
& Excess & $6-10$ & $20 \cdot 6$ & $15 \cdot 0$ & $2 \cdot 7$ & $+2 \cdot 9$ \\
& & $11-15$ & $21 \cdot 1$ & $15 \cdot 2$ & $2 \cdot 6$ & $+3 \cdot 3$ \\
\multirow{3}{*}{ Michael } & Balanced & $1-4$ & $12 \cdot 3$ & $12 \cdot 3$ & $1 \cdot 4$ & $-1 \cdot 4$ \\
& Excess & $5-11$ & $20 \cdot 0$ & $14 \cdot 9$ & $1 \cdot 7$ & $+3 \cdot 4$ \\
& & $12-18$ & $19 \cdot 6$ & $14 \cdot 5$ & $1 \cdot 6$ & $+3 \cdot 5$ \\
\multirow{3}{*}{ Sam } & Balanced & $1-4$ & $12 \cdot 4$ & $12 \cdot 5$ & $1 \cdot 1$ & $-1 \cdot 2$ \\
& Excess & $5-11$ & $20 \cdot 0$ & $16 \cdot 2$ & $2 \cdot 1$ & $+1 \cdot 7$ \\
& & $12-18$ & $19 \cdot 6$ & $14 \cdot 5$ & $2 \cdot 4$ & $+2 \cdot 7$
\end{tabular}

of the subjects was in slight negative nitrogen balance (as might be expected to result from sudden partial confinement to bed), during the time of overfeeding all three subjects were in positive balance. Making use of the factor of 6.25 for the conversion of nitrogen to protein, the amount of nitrogen retained would correspond to the daily deposition of I9, 22 and $14 \mathrm{~g}$ protein in David, Michael and Sam respectively. A small 
undetermined loss of nitrogen from the skin might make these figures somewhat less. We have also made no allowance for the probable rise of non-protein nitrogen in the body fluids. Calculations from the data of Addis (1948) indicate that this might reduce our estimate of the protein retained daily by, at the most, $\mathrm{I}$ g. Using the figure of $5.3 \mathrm{Cal} / \mathrm{g}$ protein retained in the body, these amounts of protein would account for Ioo, 116 and $74 \mathrm{Cal}$./day of the surplus calories.

\section{Gain in body fat}

The remaining surplus calories were almost certainly stored in the form of fat; it is not thought likely that they led to any increase in stored carbohydrate (see below). Taking the figure of 9.3 Cal. as the energy value of $\mathrm{I} g$ of body fat, it can be calculated that the remaining surplus calories would result in the daily deposition of 129,163 and $\mathrm{r} 60 \mathrm{~g}$ fat in David, Michael and Sam.

\section{Absence of gain in body water}

When the figures thus calculated for the daily amounts of protein and fat gained are deducted from the total gain in body-weight, as shown in Table 2, almost nothing remains. The gain in weight can be accounted for almost entirely as deposited protein and fat, with at most only a few $g$ each day left to be explained as loss or gain of water.

Table 2. Analysis of energy balance and weight changes during overfeeding in thin young men

\begin{tabular}{|c|c|c|c|c|c|c|c|}
\hline \multirow[b]{2}{*}{$\begin{array}{l}\text { Component } \\
\text { measured }\end{array}$} & \multirow[b]{2}{*}{$\begin{array}{l}\text { Method of } \\
\text { determination }\end{array}$} & \multicolumn{3}{|c|}{$\begin{array}{l}\text { Energy balance } \\
\text { (Cal/day) }\end{array}$} & \multicolumn{3}{|c|}{$\begin{array}{l}\text { Weight changes } \\
\text { (g/day) }\end{array}$} \\
\hline & & David & Michael & Sam & David & Michael & Sam \\
\hline Calorie intake (net)* & Bomb calorimeter & 3730 & 3970 & 3920 & - & - & - \\
\hline Ener & Indirect $\mathrm{c}$ & $243^{\circ}$ & & & - & - & - \\
\hline Excess calories in food & By differe & 1300 & 1635 & 1560 & - & - & . \\
\hline Gain in weight & Beam balance & $\underline{-}$ & - & $\ldots$ & 150 & 175 & 187 \\
\hline $\begin{array}{l}\text { Gain in body protein } \\
\text { and its caloric value }\end{array}$ & From nitrogen balance & 100 & 116 & 74 & 19 & 22 & I4 \\
\hline $\begin{array}{l}\text { Gain in body fat and } \\
\text { its caloric value }\end{array}$ & From energy balance & 1200 & 1519 & 1486 & 129 & 163 & 160 \\
\hline Gain in body water & By difference & - & 一 & - & +2 & - ro & $+\mathrm{I}_{3}$ \\
\hline
\end{tabular}

* Net calorie intake $=$ dietary calories - faecal and urinary calories.

\section{Possible errors}

Since these results are so different from those of Keys \& Brožek (1953), it is desirable to consider whether any error of measurement or calculation could invalidate the figures in Table 2.

Measurement of body-weight. The mean figures for the daily weight gains are factually correct for the period under observation. The weighings were carried out under standard conditions before breakfast but, owing to daily variations, the overall accuracy of the mean figures is subject to error which, however, is unlikely to exceed $15 \%$.

Measurement of caloric intake. For David the intake was determined from a duplicate of the total food consumed each day, both by chemical analyses and in the 
bomb calorimeter. The results of chemical analyses were converted into Cal. by multiplying by the factors 4,9 and 4 the value in $\mathrm{g}$ for protein, fat and carbohydrate respectively determined chemically. Table 3 shows the day-to-day analyses. The agreement between the two was so good that for the subsequent analyses only the bomb was used to determine total calories. It is less time-consuming than chemical

Table 3. Estimates of daily caloric intake (Cal.) in a thin young man (David) on a balanced diet and during overfeeding

$\begin{array}{ccccr}\text { Day } & \text { Diet } & \begin{array}{c}\text { Atwater } \\ \text { bomb }\end{array} & \begin{array}{c}\text { Chemical } \\ \text { analysis }\end{array} & \begin{array}{r}\text { Food } \\ \text { tables }\end{array} \\ \text { I } & \text { Balanced } & 2040 & 2070 & 2350 \\ 2 & & 2030 & 2030 & 2330 \\ 3 & & 2350 & 2360 & 2380 \\ 4 & & 1910 & 1950 & 2290 \\ 5 & & 2250 & 2160 & 2370 \\ \text { Mean } & & 2120 & 2110 & 2340 \\ 6 & \text { Excess } & 3630 & 3710 & 4080 \\ 7 & & 3800 & 3830 & 4120 \\ 8 & & 3550 & 3720 & 4140 \\ 9 & & 3620 & 3650 & 4120 \\ 10 & & 3780 & 3730 & 4090 \\ 11 & & 4010 & 4030 & 4020 \\ 12 & & 3640 & 3640 & 4020 \\ 13 & & 3720 & 3730 & 4150 \\ 14 & & 3880 & 3820 & 4120 \\ \text { Mean } & & 3730 & 3750 & 4100\end{array}$

analysis and no assumptions about absorption are involved. The estimations from tables were made from the tables used regularly in the Edinburgh Royal Infirmary, based on The Nutritive Value of Wartime Foods (Medical Research Council: Accessory Food Factors Committee, 1945). This calculation overestimated the caloric value of the diets by some $10 \%$. There was no significant difference between the protein contents determined chemically and from the tables, but the latter appear to have overestimated the fat by about $10 \%$. The limiting factor in the accuracy of the figures for caloric intake is undoubtedly the difficulty in weighing out an accurate duplicate of the diet eaten. Great care was taken by the dietitians, but the error can hardly be less than $\pm 4 \%$ which would mean a possible error of $100 \mathrm{Cal}$. in the daily average. It is unlikely that there was any systematic error in this weighing; daily errors would balance each other out and we would regard an overall error of \pm 100 Cal./day as a maximum.

Measurement of caloric expenditure. The accuracy of these estimates depends on how well the periods of indirect calorimetry give a fair sample of the whole $24 \mathrm{~h}$ day, and how well the daily diaries were kept. The control period provides a check on this. Table 5 in the paper of Passmore et al. (1955) shows the balance during this period. Over the longer period of excess feeding this error is unlikely to have been more than roo Cal./day.

Calculation of gain in body fat. This calculation is based on the assumption that none of the non-protein surplus calories were stored as carbohydrate. The glycogen stores 
of the normal human body amount to no more than $370 \mathrm{~g}$ (Soskin \& Levine, 1952); they are kept remarkably constant by the regulating hormonal mechanisms of the anterior pituitary, pancreatic and adrenal glands. There seems no reason-experimental or theoretical-for thinking that these mechanisms might be disturbed by overfeeding a healthy person. None of our subjects developed glycosuria.

Validity of factors used in the calculations. The factors used for calculating the caloric value of the nitrogen retained and the amount of fat equivalent to the remaining surplus calories are attested by the experience of classical physiology. They are unlikely to be in error by as much as $5 \%$.

Maximum possible error. Had we, by some extraordinary freak of sampling, consistently overestimated the food intake by $100 \mathrm{Cal}$./day, underestimated the energy expenditure by $100 \mathrm{Cal}$./day, and underestimated the weight gain by $15 \%$ in all three subjects, the remaining excess weight that could be explained as gain in body water would be 46, 57 and $62 \mathrm{~g} /$ day in David, Michael and Sam. These figures only just reach the amount of water that they should have retained had they been making 'obese tissue' as defined by Brožek \& Keys.

\section{Water balance}

The water balance can be determined from the following equations:

Gain in body water = water content of food and liquid consumed

+ metabolic water

- water content of urine and faeces

- evaporative water loss (sweat + water in expired air),

Evaporative water loss = invisible weight loss

- weight of $\mathrm{CO}_{2}$ expired

+ weight of $\mathrm{O}_{2}$ absorbed,

Invisible weight loss = weight of food and liquid consumed

+ gain in body-weight

- weight of urine and faeces.

From (I), (2) and (3) we get by addition and subtraction:

Gain in body water = gain in body-weight

$$
\begin{aligned}
& \text { + metabolic water } \\
& + \text { weight of urinary and faecal solids } \\
& + \text { weight of }\left(\mathrm{CO}_{2}-\mathrm{O}_{2}\right) \\
& \text { - dry weight of the food. }
\end{aligned}
$$

There is thus the curious anomaly that a water balance can be drawn up without any measurement of the water consumed or excreted, as was originally shown by Peters, Kydd \& Larietes (1933). In determining the water balance, the gain in bodyweight, the weight of urinary and faecal solids and the dry weight of the food were readily available. The metabolic water and the excess weight of the carbon dioxide over the oxygen had to be calculated from the foodstuffs katabolized. The protein katabolized was taken as the weight of urinary nitrogen $\times 6.25$, all the dietary 
carbohydrate was assumed to be oxidized and sufficient of the fat to bring the energy value of the diets up to the determined figures for energy expenditure. Table 4 shows the estimate of protein, fat and carbohydrate katabolized. Table 5 shows the values taken for the weights of water and carbon dioxide produced and of oxygen used for each $g$ of substance oxidized. These figures have much theoretical and experimental support. From them can be calculated the metabolic water and the weights of $\mathrm{CO}_{2}$ and $\mathrm{O}_{2}$ on each diet.

Table 4. Estimated mean weight ( $g /$ day) of proximate principles katabolized by thin young men on a balanced diet and during overfeeding

\begin{tabular}{|c|c|c|c|c|c|c|}
\hline & \multicolumn{2}{|c|}{ David } & \multicolumn{2}{|c|}{ Michael } & \multicolumn{2}{|c|}{ Sam } \\
\hline & $\begin{array}{c}\text { Balanced } \\
\text { diet }\end{array}$ & $\begin{array}{c}\text { Excess } \\
\text { diet }\end{array}$ & $\begin{array}{c}\text { Balanced } \\
\text { diet }\end{array}$ & $\begin{array}{c}\text { Excess } \\
\text { diet }\end{array}$ & $\begin{array}{c}\text { Balanced } \\
\text { diet }\end{array}$ & $\begin{array}{c}\text { Excess } \\
\text { diet }\end{array}$ \\
\hline $\begin{array}{l}\text { Protein } \\
\text { Carbohydrate }\end{array}$ & $\begin{array}{r}78 \\
220\end{array}$ & 94 & $\begin{array}{r}77 \\
260\end{array}$ & $\begin{array}{r}92 \\
482\end{array}$ & $\begin{array}{r}78 \\
260\end{array}$ & $\begin{array}{r}96 \\
482\end{array}$ \\
\hline Fat & 127 & $\begin{array}{r}35 \\
35\end{array}$ & 85 & 4 & 85 & 5 \\
\hline
\end{tabular}

Table 5. Values adopted for oxygen absorbed, carbon dioxide produced and water formed by the oxidation of I $g$ of each proximate principle

$\begin{array}{lccc} & \begin{array}{c}\text { Oxygen } \\ \text { absorbed } \\ (\mathrm{g})\end{array} & \begin{array}{c}\text { Carbon } \\ \text { dioxide } \\ \text { produced } \\ (\mathrm{g})\end{array} & \begin{array}{c}\text { Water } \\ \text { formed } \\ (\mathrm{g})\end{array} \\ \text { Protein } & 1.380 & 1.419 & 0.41 \\ \text { Fat } & 2.884 & 2.803 & 1.07 \\ \text { Starch } & \mathrm{I} \cdot 187 & 1.629 & 0.60\end{array}$

Table 6 shows the data for the water balances calculated from equation (4). There is no evidence of any increase in the retention of water during the overfeeding. Although these calculations involve a fair number of assumptions, most of the figures are derived from simple measurements and are unlikely to be subject to any important error.

Table 6. Daily mean water balance of thin young men on a balanced diet and during excess feeding calculated from equation (4), $p .3^{\mathrm{I}}$

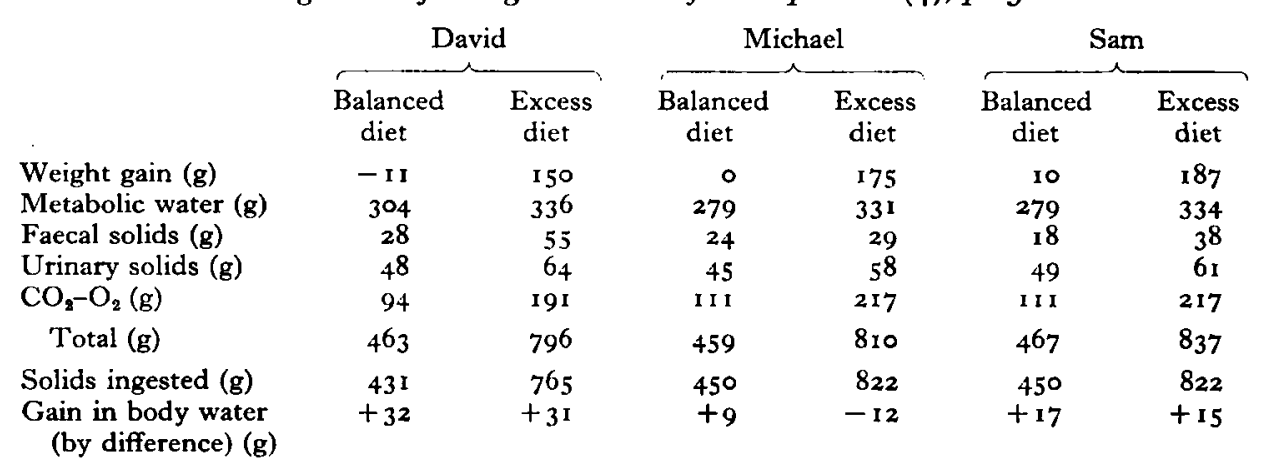


Table 7 shows the water balances calculated from equation ( $I$ ). Of course the answers are the same as those in Table 6; but Table 7 shows the figures for evaporative water loss calculated from equations (2) and (3). These figures are of interest. Newburgh ( $195^{\circ}$ ) produced evidence that in twelve persons the evaporative water loss or insensible water varied very little, and indeed a fixed proportion of the total heat loss (between 23 and $25 \%$ ) occurred through this channel. In our subjects heat loss varied from 2135 to $2430 \mathrm{Cal}$./day; $24 \%$ of it gives a range of 5 I $4-585 \mathrm{Cal}$. The latent heat of evaporation of water is $0.5^{8 \mathrm{Cal}} / \mathrm{ml}$., so that according to Newburgh the daily evaporative water losses should have been between 890 and $1000 \mathrm{ml}$. In fact the figures we obtained were in the range of $1220-1430 \mathrm{ml}$.

Table 7. Daily mean water balance of thin young men on a balanced diet and during overfeeding calculated from equation (I), $p \cdot 3^{\mathbf{I}}$

\begin{tabular}{|c|c|c|c|c|c|c|}
\hline & \multicolumn{2}{|c|}{ David } & \multicolumn{2}{|c|}{ Michael } & \multicolumn{2}{|c|}{ Sam } \\
\hline & $\begin{array}{c}\text { Balanced } \\
\text { diet }\end{array}$ & $\begin{array}{c}\text { Excess } \\
\text { diet }\end{array}$ & $\begin{array}{c}\text { Balanced } \\
\text { diet }\end{array}$ & $\begin{array}{c}\text { Excess } \\
\text { diet }\end{array}$ & $\begin{array}{c}\text { Balanced } \\
\text { diet }\end{array}$ & $\begin{array}{c}\text { Excess } \\
\text { diet }\end{array}$ \\
\hline $\begin{array}{c}\text { Intake: water in food and drink } \\
\text { metabolic water }\end{array}$ & $\begin{array}{r}2455 \\
304\end{array}$ & $\begin{array}{r}2868 \\
336\end{array}$ & $\begin{array}{r}2295 \\
279\end{array}$ & $\begin{array}{r}295^{8} \\
33^{1}\end{array}$ & $\begin{array}{r}2508 \\
279\end{array}$ & $\begin{array}{r}3348 \\
334\end{array}$ \\
\hline total & 2759 & 3204 & 2574 & 3289 & 2787 & 3682 \\
\hline $\begin{aligned} \text { Output: } & \text { urine } \\
& \text { faecal water } \\
& \text { evaporative water loss }\end{aligned}$ & $\begin{array}{r}1161 \\
132 \\
1434\end{array}$ & $\begin{array}{r}1443 \\
339 \\
1391\end{array}$ & $\begin{array}{r}1295 \\
56 \\
1214\end{array}$ & $\begin{array}{r}1750 \\
73 \\
1478\end{array}$ & $\begin{array}{r}1500 \\
52 \\
1218\end{array}$ & $\begin{array}{r}2155 \\
90 \\
1422\end{array}$ \\
\hline total & 2727 & 3173 & 2565 & 3301 & 2770 & 3667 \\
\hline Water balance (by difference) & +32 & $+3 I$ & +9 & -12 & +17 & +15 \\
\hline
\end{tabular}

Newburgh emphasized that this sharp partition of heat loss only applied if there was no visible sweating. On some days during our subjects' 90 min. walk a little visible sweating did occur, but on several occasions we measured the invisible weight loss during the walk and got figures no higher than $25^{\circ}-35^{\circ} \mathrm{g}$, only a fraction of which could be ascribed to visible sweating, which clearly could not account for the differences between our findings and Newburgh's. The ward was kept at a fairly constant temperature of $63-67^{\circ} \mathrm{F}$ throughout both day and night. At night this would be a higher temperature than that in the subjects' usual bedrooms. 'They may have used the blankets to which they were accustomed rather than the blankets which they needed. Occasionally we found visible sweat on them during the night. We cannot therefore say for certain how much of the evaporative water loss was visible or invisible, but would think it unlikely that the visible sweating was sufficient to explain the discrepancy between our figures and Newburgh's. Clearly, in studies of energy expenditure Newburgh's method requires careful watching, and it may be that the variability in different persons in the partition of heat losses is greater than his data suggest.

\section{Electrolyte balance}

Sodium and potassium balances are set out in Table 8 for all three subjects both on the balanced and on the excess diet. Each balance is small and depends on the estimation of the concentration of an electrolyte in three different materials, each estimation being subject to an error of at least $\pm 5 \%$. For this reason we would regard 
the balances in Table 8 as a qualitative rather than a quantitative statement. On the excess diet all three appeared to be losing sodium and two of the three gaining potassium, while the third was in potassium equilibrium. These results suggest that the retention of protein and fat during overfeeding is associated with the retention of other intracellular material such as potassium. At the same time there may be a shift of water from the extracellular fluid into the cells with elimination of sodium in the process. These results are consistent with the evidence from the energy and water balances, that there were no significant gains in total body water during overfeeding.

Table 8. Daily mean balances in m-equiv. of sodium and potassium in thin young men on a balanced diet and during overfeeding

\begin{tabular}{|c|c|c|c|c|c|c|}
\hline & & \multicolumn{2}{|c|}{ Credit } & \multicolumn{2}{|c|}{ Debit } & \multirow[b]{2}{*}{ Balance } \\
\hline & & Food & Condiments & Urine & Faeces & \\
\hline \multicolumn{7}{|c|}{ Balanced diet } \\
\hline David & $\begin{array}{l}\text { Sodium } \\
\text { Potassium }\end{array}$ & $\begin{array}{r}170 \\
75\end{array}$ & 30 & $\begin{array}{r}180 \\
50\end{array}$ & $\begin{array}{r}5 \\
20\end{array}$ & $\begin{array}{l}+15 \\
+5\end{array}$ \\
\hline Michael & $\begin{array}{l}\text { Sodium } \\
\text { Potassium }\end{array}$ & $\begin{array}{r}135 \\
60\end{array}$ & - & $\begin{array}{r}130 \\
55\end{array}$ & $\begin{array}{r}5 \\
10\end{array}$ & \\
\hline Sam & $\begin{array}{l}\text { Sodium } \\
\text { Potassium }\end{array}$ & $\begin{array}{r}135 \\
60\end{array}$ & 30 & $\begin{array}{r}165 \\
65\end{array}$ & $\begin{array}{l}15 \\
10\end{array}$ & $\begin{array}{l}-15 \\
-I 5\end{array}$ \\
\hline \multicolumn{7}{|c|}{ Excess diet } \\
\hline David & $\begin{array}{l}\text { Sodium } \\
\text { Potassium }\end{array}$ & $\begin{array}{l}280 \\
125\end{array}$ & $\underline{\mathbf{r}_{5}}$ & $\begin{array}{r}295 \\
70\end{array}$ & $\begin{array}{l}20 \\
25\end{array}$ & $\begin{array}{l}-20 \\
+30\end{array}$ \\
\hline Michael & $\begin{array}{l}\text { Sodium } \\
\text { Potassium }\end{array}$ & $\begin{array}{r}200 \\
90\end{array}$ & - & $\begin{array}{r}210 \\
70\end{array}$ & $\begin{array}{l}20 \\
10\end{array}$ & $\begin{array}{l}-30 \\
+10\end{array}$ \\
\hline Sam & $\begin{array}{l}\text { Sodium } \\
\text { Potassium }\end{array}$ & $\begin{array}{r}200 \\
90\end{array}$ & 35 & $\begin{array}{r}250 \\
75\end{array}$ & $\begin{array}{l}20 \\
15\end{array}$ & $\begin{array}{r}-35 \\
0\end{array}$ \\
\hline
\end{tabular}

\section{Methods}

DISCUSSION

The methods employed in this study were chosen primarily for their simplicity, but also because they are the most suitable for short-term experiments of this kind. We wished to obtain precise information about the nature of the gain in weight in these and other subjects in terms of increases in fat, cellular tissue and extracellular fluid. Methods have been elaborated for measuring these various components by determining the specific gravity of the body, the total body water and the extracellular-fluid space, but none of these methods is suitable for an experiment of this kind, in which the overfeeding lasted only IO-I 4 days and the maximum gain in weight observed was $2.57 \mathrm{~kg}$, or $4.5 \%$ of the subject's initial weight. We decided beforehand that the antipyrine method for measuring total body water was not sufficiently accurate to measure changes of this order. With David we did, in fact, measure his density by immersion in water before and after overfeeding. Similarly, in Michael and Sam we measured the 'thiocyanate space', and Dr A. G. Macgregor kindly undertook for us estimations of total exchangeable sodium and sodium space, using ${ }^{24} \mathrm{Na}$. The results of these tentative trials convince us that these methods are too inaccurate to measure small changes in bodily composition such as occur during the relatively short periods over which metabolic balances can easily be measured. Clearly some method is 
needed that will enable the metabolic balance to be accurately measured over a period sufficiently long to produce bodily changes detectable by these grosser, but more direct, measurements.

\section{Results}

The analysis of the nitrogen and energy balances during the overfeeding of these three men indicates that the whole of their gain in weight was due to the deposition of chemical substances: fat and protein. There was no evidence of any retention of water. This conclusion receives confirmation from the separate analysis of the water balances in our subjects. It is at variance with the opinion of Keys \& Brožek (1953) who believe that changes in weight in physically normal people are the result of losses or gains of 'obese tissue', composed not only of fat, but also of cellular material and water. 'Obese tissue', as defined by them, has an energy value of about $6000 \mathrm{Cal} . / \mathrm{kg}$, whereas David, Michael and Sam required 8700 , 9300 and $8300 \mathrm{Cal}$. respectively to put on $\mathrm{I} \mathrm{kg}$ of weight. Quite clearly their increase in weight was not due to the deposition of 'obese tissue'. Keys \& Brožek based their definition on an experiment in which ten male mental patients were overfed for several months; the changes in their bodily composition being measured by changes in weight, density and thiocyanate space. They claim that the character of the obese tissue gained by these men had 'a high degree of uniformity'.

Some support for the concept of 'obese tissue' is provided by the analysis of McCance \& Widdowson ( 195 r) of the composition of the body in obese people. They found that a proportion up to $30 \%$ of the excess weight above standard could be attributed to non-fatty tissue. The proportion was variable, and in women usually smaller. The presumption was that this gain in non-fatty tissue is an hypertrophy of muscle and other organs necessary to carry about and sustain the extra burden of fat. There is no evidence from their paper to show how long this hypertrophy takes to develop. It is conceivable that, in our subjects, the initial retention of protein might have been followed later by a synthesis of new cellular material involving the retention of water; but we have no evidence of this.

The logical conclusion from our results is that, over short periods at least, the healthy human body can respond to overfeeding by simply concentrating itself, by increasing the concentration of fat and protein within the existing cells. Though there is nothing new about the concept that the cells of the fat depots can take up and store a variable quantity of fat droplets, the idea that protein might similarly be concentrated and stored is less familiar. It is often assumed that the cells of the body are filled with 'protoplasm', the composition of which is fixed with the same constancy as the milieu interne or extracellular fluid which bathes them. And yet it is well known that the tissues of animals may vary considerably in their nitrogen content. The protein in the liver cells of rats, for example, is reduced by fasting (see review by Munro, 1954).

It is a familiar fact that while underfed people lose weight, there is no corresponding loss in their total body water (Keys, Brožek, Henschel, Mickelsen \& Taylor I950). It accounts for the development of 'isohydric' famine oedema (Smith \& Woodruff, I95I). Until recently it has been generally assumed that this relative excess of water is 
extracellular, but it has lately been said that the cells themselves may become diluted (Gopalan, Venkatachalam \& Srikantia, 1953). Some support for this view is provided by a consideration of the data of Widdowson ( $195 \mathrm{I}$ ) on the effects of re-feeding underfed people. She showed that their gain in weight was less than expected even if all the extra food had been stored as fat; quite clearly they lost water in the course of re-feeding. But a simple recalculation of her data shows that the measured reduction of extracellular fluid which in fact took place was not sufficient to account for the unexpectedly slow gain in weight. We suggest that her data afford evidence that water was also lost from the cells with consequent concentration of their protein content. This concentration would be accelerated by the simultaneous retention of new protein from the diet. Recent evidence shows that large amounts of nitrogen may be retained by underfed people in the course of re-feeding, without corresponding increase in their body-weight (Bray, 1953; Holmes, Jones \& Stanier, 1954). Another circumstance under which protein accumulates in the body is in the treatment of patients with androgenic hormones (Kochakian, 1946). Although this accumulation is usually accompanied by some gain in weight, we can find no published evidence that the gain is always commensurate with the nitrogen retention, indicating the synthesis of new protoplasm of fixed protein content. Incidentally, Holmes et al. (1954) have recently suggested that adrenal cortical hormones may be concerned in the nitrogen retention that occurs during recovery from starvation. It seems likely that the androgenic hormones may prove to be especially important.

We are tempted to suggest that the protein content of the cells may vary continuously along the whole 'emaciation-obesity continuum' (to use Ancel Keys's phrase), and that at no point will it prove possible to say that an individual has 'normal' protein nutrition because his cells contain a certain fixed and desirable concentration of protein.

The study described in this and the preceding paper (Passmore et al. 1955) still leaves unanswered the simple question: how is it that these three young men manage to keep themselves thin? When overfed they quickly put on weight, though not as much as expected. It could be suggested that their apparent ability to concentrate their cellular material explains their resistance to the ill-effects of gluttony. But obviously this process cannot be continued indefinitely. Had we continued the experiment for several months, would they have become fat? We doubt it and suspect that after a time they would have refused the extra food which they so willingly took for a short period. Presumably their appetite keeps them thin. In a complicated society such as ours, when we begin our meals is determined by social circumstances and custom rather than need. The physiological control possibly comes in by determining when we stop eating. How does such a control operate? What satiates appetite? A full stomach is not the simple answer. Is there some metabolite, rapidly produced, that controls our intake of food? 


\section{SUMMARY}

I. Three constitutionally thin young men were overfed under standard conditions for periods of 10-14 days.

2. Their gain in weight was less than three-quarters of the gain that should have been expected had the excess calories in their diet gone to make 'obese tissue' composed of fat, cellular material and extracellular fluid.

3. The nature of the material responsible for the gain was investigated by measuring the balances of energy, nitrogen, water, sodium and potassium.

4. The gain in weight in these thin men appeared to be due entirely to deposition of fat and protein. There was no evidence of any gain in body water.

We have to thank Professor D. M. Dunlop for allowing us the use of three beds in his ward and for providing every facility for this study. We are grateful to David, Michael and Sam for cheerfully doing what they were told and eating what was set before them. We have to thank the Medical Research Council for a grant for expenses and a personal grant to one of us (R.K.T.).

\section{REFERENCES}

Addis, T. (1948). Glomerular Nephritis. New York: The Macmillan Co.

Bray, B. (1953). Brit. Y. Nutr. 7, 3 .

Gopalan, C., Venkatachalam, P. S. \& Srikantia, S. G. (1953). Metabolism, 2, 235.

Holmes, E. G., Jones, E. R. \& Stanier, M. W. (1954). Brit. Y. Nutr. 8, 173.

Keys, A. \& Brožek, J. (1953). Physiol. Rev. 33, 245.

Keys, A., Brožek, J., Henschel, A. F., Mickelsen, O. \& Taylor, H. L. (1950). The Biology of Human Starvation. Minnesota: University Press.

Kochakian, C. D. (1946). Vitam. E Horm. 4, 255.

McCance, R. A. \& Widdowson, E. M. (1951). Proc. roy. Soc. B, 138, 115.

Medical Research Council: Accessory Food Factors Committee (1945). M.R.C. (War) Memor. no. 14.

Munro, H. N. (1954). Proc. Nutr. Soc. 13, I15.

Newburgh, L. H. (1950). In Clinical Nutrition, p. 689. [N. Jolliffe, B. F. Tisdall and P. R. Cannon, editors.] New York: Paul B. Hoeber Inc.

Passmore, R., Meiklejohn, A. P., Dewar, A. D. \& Thow, R. K. (1955). Brit. F. Nutr. 9, 20.

Peters, J. P., Kydd, D. M. \& Larietes, P. H. (1933). F. clin. Invest. 12, 689.

Sanctorius, S. (1614). Ars Sanctorii Sanctorii. De Statica Medicina, Aphorismorum Sectionibus Septem Comprehensi Accesit Staticomostix sive ejusdem Artis Demolitio Hippolyti Obicii. Venice.

Smith, D. A. \& Woodruff, M. F. A. (1951). Spec. Rep. Ser. med. Res. Coun., Lond., no. 274.

Soskin, S. \& Levine, R. (1952). Carbohydrate Metabolism, and ed. Chicago: University Press.

Trevelyan, W. E. \& Harrison, J. S. (I952). Biochem. F. 50, 298.

Widdowson, E. M. (1951). Spec. Rep. Ser. med. Res. Coun., Lond., no. 275, p. 3 I 3. 